\title{
Next Steps for Animal Rights
}

\author{
Professor David Favre \\ Professor of Law, Michigan State University College of Law, USA
}

Recommended citation. FAVRE, D., Next Steps for Animal Rights, dA. Derecho Animal (Forum of Animal Law Studies) 10/1 (2019) - DOI https://doi.org/10.5565/rev/da.414

\begin{abstract}
Over the past decade, the fifty state legislatures of the United States have been adopting legislation for the benefit of the group of animals known as companion animals. When considered together as a set, these laws create an initial set of legal rights for that group of animals. To explore that conclusion, the definition of a legal right and the particular statutes, such as new divorce laws, must be considered.
\end{abstract}

Key Words: animal rights; animal interest; companion animals; victims; trust; divorce.

Resumen - Próximos pasos en Derechos de los Animales

A lo largo de la última década, en los cincuenta estados de los Estados Unidos de América, se han ido promulgando leyes en favor de aquellos animales que conocemos como animales de compañía. Cuando dichas leyes se contemplan en su conjunto, podría decirse que tales leyes han sentado las bases para el reconocimiento de derechos en favor de los animales de compañía. Para someter a estudio esta afirmación, hay que tomar en consideración qué se entiende por un Derecho reconocido legalmente, así como también las leyes promulgadas por cada Estado, como es el caso de las recientes leyes de divorcio.

Palabras clave: derechos de los animales; intereses de los animales; animales de compañía; víctimas; fideicomiso; divorcio.

Many of the articles in this esteemed publication have used the phrase "animal rights". Nearly everyone writing for this publication and reading the articles are in favor of animal rights. However, my forty years of experience in this field suggest that most people do not actually know what the phrase means in the world of law, or how the animals will get them, or how it would affect specific animals.

In the European Union and other civil law countries considerable energy has been spent in establishing, as a first order of action, the creation of a new legal category for animals. ${ }^{1}$ While this is all very good, it does not by itself create any new legal rights in animals. In the U.S. we have the valiant efforts of the Nonhuman Rights Project in seeking to establish that a chimpanzee or elephant is a legal person under the common law cause of action known as habeas corpus, which to date has not been successful. ${ }^{2}$

${ }^{1}$ GIMÉNEZ-CANDELA, M., The De-Objectification of Animals in the Spanish Civil Code, dA. Derecho Animal (Forum of Animal Law Studies) 9/3 (2018) 28-47 (https://doi.org/10.5565/rev/da.361).

${ }^{2}$ Nonhuman Rights Project, Inc., on Behalf of Tommy, v. Lavery, 124 A.D.3d 148 (S. Ct, 3rd Dept. NY, 2014); Matter of 
One key misperception held by many is that a set of "rights" will be granted to all animals in one sweeping statement of legislation. This is actually highly unlikely. The world is too complex with too many human economic and cultural issues in conflict to resolve all the animal issues with one law. The nature of our law creation process is piecemeal, by topic. Legal rights arise for various communities or species of animals. Those in commercial food facilities are treated differently from those who live with us, and from those used in entertainment. For the following discussion, the focus will be solely on "Companion Animals", as they are the group of animals who presently are receiving legal rights in the United States. Their presence and importance in the core of the family is now recognized by various legislatures. ${ }^{3}$

Before we can proceed, careful consideration of just what is a legal right is necesary. How do we recognize one when it is created? While the jurisprudence of legal rights is very complex, for the purpose of animals I think a relative narrow focus is sufficient. Animals have individual interests arising out of genetic inheritance and individual personality, just like humans. Each animal has his or her own needs and desires. Anyone with a companion animal is aware that their animal is a unique being. A legal right for animals exist when someone in the legal structure first acknowledges their existence as individuals (it helps if they have names) and then takes into account their needs and interests when making a legal decision that will have an impact on that animal.

The most active and positive arena for legal change is in the fifty state legislatures of the United States. There have been many laws adopted throughout these fifty states that provide both visibility and protections for the four-legged family members. ${ }^{4}$ The following is just a sampling, and not meant to be a comprehensive survey. Note how companion animals are moving closer to the status of young human children. Two categories in which to consider the increasing visibility of companion animals is criminal law and family law.

\section{Animals as Victims of Crimes}

As with all areas of law, animals are initially, historically, seen as property. One recent case suggests that the status of animals within the criminal legal system are moving into a new phase. This deals with a fundamental conceptual view of what is an animal, simple property or individuals, acknowledged as such. If someone breaks into a home, and destroyed some furniture and perhaps a computer, the personal property is lumped together, and it would be considered one crime for purposes of sentencing a guilty defendant. In 2018, the Oregon Supreme Court had the issue come before them in the context of the sentencing a defendant, where the state wanted 11 counts of violation of the cruelty law, one count for each animal that has been harmed by the defendant. ${ }^{5}$ The defendant claimed the actions merited only one count and therefore he should receive a lesser sentence of jail time. The Court held that each animal was a victim and therefore that the charge of eleven counts was correct. This is the first time a high court has allowed an animal the status of a victim in the context of human criminal law.

\section{Representation}

On the other side of the country, another new step was taken for dogs and cats caught up in criminal proceeding against human actors. It is now customary to provide an opportunity for the human victim of a crime to have a voice in the proceedings, particularly at the sentencing stage. What happens when the victim is an animal? For dogs and cats, being members of that special class of companion animals, this is now happening in the state of Connecticut. Under a 2017 law, ${ }^{6}$ the court may appoint an attorney or a law student to aid the court in a criminal anti-cruelty proceeding. Law students at the University of Connecticut are actively taking advantage of this power and have been appointed to help in a number of cases.

\section{Extra Protection for Companion Animals}

The legal system has long provided protection for animals against intentional acts of cruelty and the

Nonhuman Rights Project, Inc. v Lavery, 31 N.Y.3d 1054, 100 N.E.3d 846 (2018).

${ }^{3}$ For full discussion of the science of the importance of companion animals to the humans who have them, see, FAVRE, D., DICKERSON, D., Animal Consortium, Tennessee Law Review, 84 (2017) 839.

${ }^{4}$ For a detailed consideration of this issue including the science of why companion animals can be important for the human members of the family see, FAVRE, D., DICKERSON, D., Animal Consortium, Tennessee Law Review, 84 (2017) 839.

${ }^{5}$ Oregon v. Crow, 294 Or. App. 88 (2018).

${ }^{6}$ Conn. G. S. A. § 54-86n.

22 Derecho Animal. Forum of Animal Law Studies, vol. 10/1 
unnecessary infliction of pain and suffering. The introduction of aggravated animal cruelty legislation has been among the more significant recent changes. The State of Illinois, for instance, adopted a special provision under the title "Aggravated Cruelty" as follows: "No person may intentionally commit an act that causes a companion animal to suffer serious injury or death." " Liability under general animal cruelty law provisions are usually qualified by or conditioned on various factors such as "unnecessary", "knowingly" and "cruelly". The language from the Illinois statute is, however, without qualification. Therefore, if, while driving a car in Illinois, a person intentionally runs over a cat or, alternatively, a raccoon, both acts would be a crime. However, hitting the cat would be a much more serious crime. ${ }^{8}$

\section{Animal Abuser Registry}

Another example of the criminal law providing increasing consideration to the importance of animals is the creation of an Animal Abuser Registry. These state registries parallel the registries for those who have been convicted of sex abuse crimes. For example, see the provision from the Tennessee Animal Abuser Registration Act adopted by Tennessee in 2015. ${ }^{9}$ The Registry is a public internet database with the name, addresses and crimes of defendants.

\section{Trust \& Will}

It is now accepted in all fifty U.S. States that pet trust, the setting aside a sum of cash for the care of companion animals, can be created in a personal will or a freestanding trust. ${ }^{10}$ Again, the pet is in almost the same legal status as that of a child. The courts have the power to force the trustee to abide by the conditions of the trust for the benefit of the animals named in the trust.

\section{Companion Animals in Hot Cars}

In 2018 Louisiana enacted a law that grants immunity to Good Samaritans who forcibly enter a motor vehicle to save minors (children), or dogs and cats in distress. ${ }^{11}$ Under Louisiana law, there is no liability on the part of a person for property damage or trespass to a motor vehicle, if the damage was caused while the person was rescuing a minor or an animal in distress. Note that nearly identical statutory language is used for both human children and dogs and cats. Over a dozen states have passes such laws. ${ }^{12}$

\section{Restraining Orders}

Another area where companion animals have legal visibility is when the courts' grant personal restraining orders. In the fall of 2016, the State of Alaska modified existing divorce law to allow victims of domestic violence to seek an order for protection of property including "a pet, regardless of . . . ownership." 13 The new provisions also allow a court, in the context of a protection order request, to order the payment of funds by the named party for not only support for the adult victim and minor children, but, also for pets in the care of the petitioner. ${ }^{14}$ In this context, a companion animal is provided protections similar to those of a child. By the end of 2016, thirty-two states had protective order provisions that included animals. ${ }^{15}$

\section{Divorce}

Until 2017, in all fifty states, the divorce laws did not distinguish a dog or cat from other personal property in judicial divisions of property. In that year Alaska was the first state to adopt a new provision for

\footnotetext{
7510 Ill. Comp. Stat. $70 \S 3.02(a)$.

${ }^{8}$ Also see, Tenn. Code Ann. § 39-14-212.

9 Tenn. Code Ann. Sec. 40-39-103.

10 Unif. Trust Code $\S 408$, UNIF. LAw COMM’N 2000.

${ }^{11} \mathrm{http}: / / w w w . l e g i s . l a . g o v /$ legis/ViewDocument.aspx?d=1101104.

${ }^{12}$ For more detailed information on these laws, please visit the comparative law table on the topic: https://www.animallaw.info/topic/table-state-laws-protect-animals-left-parked-vehicles.

${ }^{13}$ Alaska Stat. $\$ 18.66 .100(c)(10) 2016$.

${ }^{14}$ Alaska Stat. $\$ 18.66 .100(\mathrm{c})(12) 2016$.

${ }^{15}$ WISCH, R., Domestic Violence and Pets: List of States that Include Pets in Protection Orders, Animal Legal \& Hist. Ctr., https://www.animallaw.info/article/domestic-violence-and-pets-list-states-include-pets-protection-orders.
} 
companion animals, followed shortly thereafter by Illinois and California. The Alaska law allows the relevant court to make specific provision in a final divorce judgment: "for the ownership or joint ownership of the animal, taking into consideration the well-being of the animal. (emphasis added)"16 This statute clearly acknowledges that animals have interests independent of those of the spouses and that those interests deserve consideration by the legal system when a divorce proceeding impacts the animal.

\section{Removal of an Animal from a Home}

Another parallel between the legal protection of companion animals and children manifests when the state seeks the removal of the animal from the household to protect the animal from the risk of future harm. If the owner of an animal has been charged with a criminal violation of state anti-cruelty law, perhaps beating an animal or failing to provide adequate care for an animal, then even before the criminal charges are decided, the state may seek the removal of the animal from the defendant's control with a forfeiture action. ${ }^{17}$

\section{Joining the Family on a Dinner Night Out}

In 2018, Ohio joined 10 other states that have laws allowing restaurants to maintain "dog friendly" patios. ${ }^{18}$ The new law provides a "retail food establishment or food service operation" the ability to allow dogs in outdoor dining areas provided some requirements are met. These laws suggest, again, that the public is increasing accepting that companion animals are part of the intimate family, and that they be extended the privileges joining their family when the humans are out on the town for dinner.

\section{Conclusion}

All of the above legislation occurred without anyone mentioning "animal rights," rather, it was the perceived as right thing to do by the elected legislators, to protect and acknowledge these new important members of the human family. These quiet steps forward have arisen naturally, as those with concerns about the animals convince legislators to do the right thing. If you want to obtain legal rights for animals, I suggest a strong focus on family and criminal law.

I as all the readers to assess their jurisdiction, with a focus on companion animals, and determine which next steps for the animals is possible. And, remember they may be modest. The tallest building is built one brick.

\section{Bibliography}

- FAVRE, D., DICKERSON, D., Animal Consortium, Tennessee Law Review, 84 (2017) 839.

- GIMÉNEZ-CANDELA, M., The De-Objectification of Animals in the Spanish Civil Code, dA. Derecho Animal (Forum of Animal Law Studies) 9/3 (2018) 28-47 (https://doi.org/10.5565/rev/da.361).

- WISCH, R., Domestic Violence and Pets: List of States that Include Pets in Protection Orders, Animal Legal \& Hist. Ctr., https://www.animallaw.info/article/domestic-violence-and-pets-list-states-include-petsprotection-orders.

\footnotetext{
${ }^{16}$ Alaska Stat. $\$ 25.24 .160(a)(5)$ 2016. (emphasis added). Also see, 750 Illinois Codified Statue 5/501 - 503; Calif. Family Code $\S 2605$.

${ }^{17}$ Mich. Comp. Laws Anno. § 750.50(3).

${ }^{18}$ The bill amends section 3717.05 of the Ohio code and enacts section 3717.14 of the Revised Code. 